\title{
Dismissal of Village Officials According to Sumbawa Regency Regional Regulation Number 3 of 2015
}

\author{
Athar Agung Ramadhan; H. M. Galang Asmara; H. Kaharuddin \\ Master of Law, Faculty of Law, University of Mataram, Mataram, Indonesia \\ http://dx.doi.org/10.18415/ijmmu.v8i10.3055
}

\begin{abstract}
The village head has an urgent function in development, empowering village communities. As a village head, as a public office, the decisions taken must comply with legality, the principle of protection of human rights, and the general principles of good governance. The fact is, the village government's problems do not always run smoothly because they get rejection and resistance from the community. The refusal and resistance, even to the point of legal issues or resolved through reporting. One of the cases occurred in the Berora Village administration, Lapok District, Sumbawa Regency, in the form of a decision by the Village Head to dismiss four Regional Heads. The above case basically will not happen if the principles of legal certainty and orderly administration of government according to the Sumbawa Regency Regulation Number 3 of 2015 can be carried out correctly. Researchers made in-depth observations of the subjects involved, starting from the Village Head, Hamlet Head, BPD Desa Berora, Camat Lapok, and possibly an in-depth investigation of the regional regulations themselves through the Sumbawa Regency law bureau. The results showed that the Dispute on the dismissal of the Village Apparatus by the Village Head of Berora resolves through two media, namely Administrative Efforts and the Mataram State Administrative Court. The decision has given through administrative efforts (Camat, strengthened by the Head of the Village Community Empowerment Service and the Regional People's Representative Council through Commission one decided that the dismissal of the Berora Village Apparatus must be annual.
\end{abstract}

Keywords: Dismissal; Village Apparatus; Regional Regulation

\section{Introduction}

The practice of the government system in Indonesia regarding the central government, provincial government, district/city governments, sub-districts, sub-districts, and villages. The governance structure at each level links to the concepts of decentralization, concentration, and co-administration. The village government is the smallest government, which in its implementation gives the right of autonomy.

There is great potential and, at the same time, complex problems that must manage appropriately so that the village government emerges as a mover and accelerates the realization of equitable distribution of community welfare. The government's attention to village government implemented in the Ministry of Villages, Development of Disadvantaged Villages, and Transmigration. In particular, as a state of the law, the Indonesian government also regulates village government through Law Number 6 of 2014 concerning 
Villages. The potential in the village is the ownership of natural resources and the number of human resources, one side of the problems that exist starting from the low quality of education, health, and economy and exacerbated by the high gap with urban communities.

The enactment of Law Number 6 of 2014 to position the village as an honorable subject in the Indonesian constitution, determine the appropriate village format in local diversity, position the town as a subject in development and governance. There are various policy implementations with the existence of this law, one of which is the distribution of village funds which is quite large, which has an impact on political aspects (the lively Pilkades) and social in the village government.

Village government managed by the Head assisted by village officials or other designations in charge of implementing village government, carrying out village development, developing village communities, and empowering village communities. Village communities with a relatively large number, for West Nusa Tenggara Province at least per village with a total of 2,500 people or 500 families. The village head is a regional leader who is in direct contact with the community. In this modern era, not only relying on authority, descent and others, but the adequate potential is needed so that community development and empowerment can run, even the use of appropriate technology in mobilizing village potential.

The village head, from the beginning of the village's existence until now, is a prestige. Initially only from certain village groups, but in line with changes in time, following the statement above, that the community's needs were not limited to the authority and descendants of the village elite. Also, the ability to lead and manage resources, the village community who feel adequate competence do not hesitate to nominate himself as village head. Empirical facts that exist, the village elite is increasingly strengthening its role in determining village heads and government ranks so that their influence in the village community does not fade.

The village head manages the village government, assisted by village equipment, including the Village Consultative Body, Community Institutions, Customary Institutions, and even the village community. In Government Regulation Number 43 of 2014 and the legislation below (Governor Regulation, Regent Regulation, and Village Regulation). The Village Head has an urgent function in development, empowering village communities. The Village Head election process was carried out in such a way, including his duties, procedures, and authorities during his tenure.

The term of office of the Village Head is six years and can elect three times in a row. This provision can be potential as well as a threat to the implementation of village functions in accelerating the empowerment and welfare of rural communities. However, the law also protects village heads in making development policies. The policy in question is a policy that has the proper process and, at the same time, the correct result (context of estimation, planning, or realization). The correct procedure is through the involvement of other village apparatus functions, including the Village Supervisory Board (BPD), even the community if there are active activities in providing input on the policy of the Village Head.

In total, the Village Head is a public office. Therefore, the decisions taken must comply with the principles of legality, the focus of protecting human rights, and the general principles of good governance. The principle of legality indicates that a decision "(a written decision issued by a Government Agency and Official in the administration of government)" must be following the laws and regulations governing the decided cargo. The laws and regulations follow the hierarchy in the form of a) the 1945 Constitution; b) MPR decisions; c) Laws/Government Regulations in place of Laws; d) Government Regulations; e) Presidential Regulation; f) Provincial Regulations and g) Regency/City regulations.

The above is reinforced by the principles in village governance, in the form of the principles of a) legal certainty; b) orderly administration of government; c) orderly public interest; d) openness; e) proportionality; f) professionalism; g) accountability; h) effectiveness and efficiency; i) local wisdom; j) 
diversity, and k) participatory. The village head, village apparatus, community, and all other components must know and understand the meaning of this principle; there will be no complex problems.

The fact is, the village government's problems do not always run smoothly because they get rejection and resistance from the community. The refusal and resistance, even to the point of legal issues or resolved through reporting. One of the cases occurred in the Berora Village administration, Lapok District, Sumbawa Regency, in the form of a decision by the Village Head to dismiss four (4) Hamlet Heads, namely the Strange Hamlet Head, Sekayu Hamlet Head, Berora Hamlet Head, and Ramolong Hamlet Head and five (5) officials. Other villages (Head of Government Section and others).

The above case basically will not happen if the principle of village governance is implemented. One of the principles is legal certainty and orderly administration of government. In this context, there are explicit references to the duties, functions, and authorities of the Village Head. On the other hand, there are also laws governing the procedures for dismissing or dismissing village officials - the Sumbawa Regency Government through the Sumbawa Regency Regional Regulation Number 3 of 2015 concerning Village Apparatus.

The research objectives expected in the study are (1) To find out and analyze how the regulation of the dismissal of village officials according to the Sumbawa Regency Regional Regulation Number 3 of 2015. (2) To find out and analyze the legal consequences of the dismissal of village officials that are not following the Sumbawa Regency Regional Regulation Number 3 of 2015.

\section{Literature Review}

\section{Rule of Law Theory}

The rule of law shows that the state is run by law, not by power. One thing that needs to explain is that based on the law, it shows the applicable law, according to its content and its content, it is confident that it is impartial to all levels of society. However, based on law, it does not mean that all matters resolve through the trial. For example, the journal presented the case of Granny Minah, who was on trial because she was only accused of stealing three cocoa pods. The loss of state enterprises is not much, but lawsuits that exist are sentenced to 1.5 years. Compared to the sentences of corruptors in the number of billions. This context is not referred to as the rule of law. However, the practice of law must provide guarantees of justice in applying human rights and must take sides with the community's welfare.

The essential elements in the rule of law are 1) guarantees of human rights; 2) separation/sharing of power; 3) government legality; 4) free and impartial administrative justice; and 5) the realization of the general welfare of citizens. Therefore, all parties, primarily through the people's representatives (DPR/DPRD), work optimally in drafting laws that favor the community.

Especially in Indonesia, making laws is the right of the legislature and the executive (such as government regulations instead of laws, government regulations, presidential decrees, ministerial regulations, governor decisions, to village head decisions). There are forms of legislation that result from cooperation between the legislature and the executive. There are also those produced directly from the executive in the context of elaborating a law. The role of the administrative makes regulations to carry out the law. For this reason, the part of all parties in carrying out supervision must carry out. The implementation level may have different meanings and purposes with the legislation, thereby harming the community's interest. The awareness of the Indonesian people in general on this aspect is still very lacking, so it is necessary to give high appreciation to the individual and institutional parties who focus on this aspect. In its work, the Constitutional Court often carried out a judicial review. 
The existence of the rule of law is basically to prevent absolute power in the regime. On the other hand, the elites try to manage the law for the benefit of their group. This condition occurs in the village and state governments (Indonesia), carried out by controlling parliament (DPR seats) and coalition with political parties. Its existence is not as a supervisor for the community's interests, but it smooths the presence of the elite or regime.

The theoretical concept expressly states that one of the rules of law states is welfare-oriented. This theory is an effort of resistance from capitalist or socialist countries, where economic actors constantly try to be in the realm of power holders to support their interests. Indonesia can ascertain as law state with the characteristics of economic development for welfare people. As a state of the law, Indonesia is clearly and unequivocally stated in paragraph 3 of article 1 of the 1945 Constitution. The orientation of national economic development was explained in article 33. The direction of welfare state law for the Unitary State of the Republic of Indonesia is unique, carried out jointly based on the principle of kinship (paragraph 1). The national economy is organized based on economic democracy with the principles of togetherness, efficiency with justice, sustainability, environmental insight, independence, and maintaining a balance of progress and national economic unity (paragraph 4). This context must be the principle of Indonesia as a state of welfare law. The developed economy as a result of joint work. The orientation of the country's economic growth as a contribution from all parties impacts low economic inequality or economic equality. Although this context is ideal, empirically, it is still far from the ideal.

\section{Legislation Theory}

The two problems raised in this research examine the law, the first in the judicial context. It means that the law is reviewed using other rules following its hierarchy and the laws governing the formation of these laws. The second problem uses an empirical context, where the subject in the dispute uses which legislation reference. It was emphasized that, because the Village Head could not be declared to be working without a basis, the Village Apparatus also objected to having specific legal guidelines.

Bagir Manan provides limits on the meaning of legislation, as follows: 1) Legislation is a written decision issued by an authorized official or office environment, containing general binding rules of conduct; 2) Are rules of behavior that contain provisions regarding rights, obligations, functions, status, or order and 3) Are regulations that have general-abstract or abstract-general characteristics, meaning that they do not regulate or aim at particular concrete objects, events or phenomena.

\section{Authority Theory}

Authority in the sense of language (Big Indonesian Dictionary) defines as 1) the right and power to act; authority; 2) the power to make decisions, rule, and delegate responsibility to others. Authority (English: authority) is the right to do something or to order others to do or not do something to achieve specific goals. Authority arises because a position attached to the place disappears in line with the release of the related part.

Positions held by state apparatus in public or government organizations to ensure that can realize shared goals. Authority means the ability to carry out a public legal action or juridically is the ability to act given by the applicable law to carry out legal relations. Thus, the government's authority has the following characteristics: a) express implied; b) clear intent and purpose; c) bound at a specific time; d) subject to written and unwritten legal limitations, and e) the contents of the authority can be general (abstract) and concrete.

There are at least three components in authority, namely a) the influence component: the control of the behavior of legal subjects intend to use of authority; b) the legal basis component, that the authority must always be able to designate the legal basis; and c) legal conformity component, which implies the 
existence of a standard of authority, both general standards (all types of authority) and specific standards (for certain types of authority).

\section{Theory of Justice}

The theory of justice from John Rawl, as one of the modern era theories of justice. His views on justice are:

a. Everyone should have an equal right to the broadest comprehensive system of fundamental liberties. This principle concerns the distribution of basic freedoms, which need to be equally distributed to everyone. These fundamental freedoms include the right to vote and hold state office, freedom of speech and assembly, freedom of conscience, freedom of thought, freedom of personality, right to own personal property, and freedom from arbitrary detention and arrest.

b. Should arrange Social and economic differences in such a way as to 1) provide the most significant benefit to those in the most disadvantaged position, b) relate to positions and positions which are open to all based on formal equality of opportunity.

Of course, this study will also describe several other theories of justice. The idea of justice was also developed by Susana, as follows; 1) God wants human relations to always to be based on justice as a mirror of the first precepts; 2) justice is a prerequisite for the fairness of human relations, as a mirror of justice from the second precept; 3) justice as an absolute requirement for the realization of Indonesian unity, as a mirror of justice from the third precept; 4) democracy as a demand for justice, a mirror of justice from the fourth precepts and 5)the structures of the process of community life contained in the political, economic, social, cultural and ideological fields are arranged in such a way that justice is achieved, as a mirror of justice from the fifth precept. Justice in this study is to measure the obedience obtained from the positions of the Village Head and Village Apparatus as parties who have their respective duties, powers, and rights to realize the goals of the Indonesian rule of law.

\section{Village Concept}

As an autonomous region, the village has the authority to regulate internal government over the interests and initiatives of the government. It is also still open or may be declared to have to obey orders from the government above it (sub-district, city/district, and the next level). The meaning of government outside rule is that the village government can see from the Law on the Village Head definition. Meanwhile, in the sense of the village, it seems to carry out complete autonomy. This context can be the basis of conflict when the Village Head makes a decision. It turns out that the assessment is different from other officials.

The Village Head is a "Village Government official who has the authority, duties, and obligations

to organize his Village household and carry out the Government and Regional Government." The obligation to carry out orders from the provincial and district/city governments can also be seen in article 22 of Law Number 6 of 2014, that the assignment from the government and the local government to the village government is in the form of village administration, village development, coaching and empowerment of rural communities.

Article 26 of Law Number 6 of 2014 described the duties, powers, rights, and obligations of the Village Head. The Village Head is in charge of "administering Village Administration, implementing Village Development, developing Village community and empowering Village communities." In translating the task, it is still necessary to refer to the guidelines of government officials in carrying out their roles. In carrying out these duties, the Village Head makes decisions. The decision is the decision of the government apparatus. It strengthened or vice versa in changes, revocations, delays, and cancellations of decisions in the decision process. 
Decisions can be changed if there are 1) errors of the preamble, 2) editorial errors, 3) changes in decision making, and 4) new facts. The revocation of the decision can occur if the authority, substance, and procedure are defective. The government apparatus can also delay the decision if it is possible that 1) state losses occur, 2) environmental damage, and or 3) social conflict. Finally, restrictions can occur if there is a defect in authority, procedure, and or substance.

The Village Head, in carrying out his duties, his authority must study well the conditions of the right decision. The Village Head must return to the beginning of the principles of good governance and study government administration. Then, the decisions made can run well and do not become a problem for his position. Authority of the Village Head, one of which is to appoint and dismiss Village Apparatus. This decision must meet various elements so that it does not fall into multiple amended, postponed, or canceled categories due to acts stipulating various reasons.

\section{Village Apparatus}

The village apparatus/apparatus/apparatus is the party affected by the decision of the Berora Village Head, in the form of dismissal. Village apparatus are personnel in the village government whose role is to assist the Village Head in carrying out his duties and authorities. The village apparatus consists of the village secretary, regional executive, and technical implementer.

The appointment of the Village apparatus is not as absolute as the Principal's prerogative because he must consult with the sub-district head. Therefore, although a system regulated in the Law carries out the Village Head authority, it is also for dismissal that the decision must consult with the sub-district head.

In carrying out its work, the Village Apparatus is responsible to the Village Head. Village apparatus personnel requirements, in the form of 1) minimum high school education; 2) Ages 20-42;3) local villagers for at least one year; 4) other conditions determined by the Regional Regulation. Operational requirements as implementing rules are explained in the Regional Regulation in the Sumbawa Regency through the Sumbawa Regency Regional Regulation Number 3 of 2015.

The task carried out by the Village Apparatus is to assist all the functions of the Village Head following the task areas specified in the organizational structure. On the one hand, the village head must ensure that all his assistants can work optimally so that the village government can realize the objectives correctly.

\section{Methods}

The type of research used is normative legal research, which is "legal research conducted by examining library materials (secondary data), including research on legal principles, legal systematics, vertical and horizontal synchronization, legal comparisons or legal history." In this study, a study of the principles and legal content of the legislation governing the Village Head and Village Apparatus was carried out, and the vertical synchronization of related legislation. The results of this study are essential because they will be a signal from the Village Head in making a dismissal decision and, on the one hand, the legal reasons used by the Village Apparatus to fight the law.

Normative legal research is "legal research that puts the law as a building system of norms." This study is not only limited to using the rule of law and other aspects that have been set out above but also focuses on cases that exist in the object of research so that there is an empirical approach. The research will also find out how the Village Head manages the government, the basis for dismissal, both the juridical basis used or the case of the condition of the Village Apparatus in carrying out their functions and duties. Likewise, it is carried out on the side of the State Apparatus, so this research will find factual mechanisms carried out by the Village Head in carrying out dismissals, including the tool carried out by the Village 
Apparatus in carrying out legal resistance. Through the second problem, which is approached by empirical legal research.

The technique of collecting legal materials (all in the form of document data) is carried out by recording, copying, and downloading from the government's official website (website) that issued the legislation. Especially for primary data, it was conducted using in-depth interview techniques, both with the Village Head, Village Apparatus, BPD, Camat, Sumbawa Regency Law Bureau, and community elites (community leaders who know the social conditions of Berora Village).

Legal Material Analysis in this research is to study in-depth (principles and content) of Law Number 12 of 2011 as the basis for studying the laws and regulations relevant to this research, particularly the articles concerning Village Apparatus, Village Heads, and Villages. Therefore, an analysis was carried out on Perda Number 3 of 2015 relating to the Village Apparatus, including the terms and mechanisms for its dismissal. In addition, a study of principles, such as clarity and others, was carried out so that the related articles were found (guidelines for the Village Apparatus at work, including the basis of the Village Head in dismissing or other staffing actions).

This research strengthens by conducting in-depth observations of the subjects involved, starting from the Village Head, Hamlet Head, BPD Desa Berora, Camat Lapok, and possibly an in-depth investigation of the regional regulations themselves the Sumbawa Regency law bureau. Related to this combination of judicial and empirical research (mix research), it can contribute specifically and in general to the village head's policies, particularly the apparatus's dismissal. All of these studies are expected to lead to law-abiding, which can then accelerate the implementation of the apparatus's duties in community development and empowerment.

\section{Result}

\section{Regulation of Dismissal of Village Apparatus-Regional Regulation of Sumbawa Regency Number 3 of 2015}

Village Government is a government that spearheads service, development, empowerment, and various state tasks to the community. Aware of this task, all aspects of the village administration are regulated. First, the primary regulation through Law Number 6 of 2014, its implementation is regulated in Government Regulation Number 43 of 2014, then in a Regional Regulation, specifically in the form of Regency Regulation Number 3 of 2015.

The Village Government is the organizer of the Village administration for the benefit of the Village community in the realm of the unitary state of the Republic of Indonesia. The government's party is in the form of the Village Head, assisted by the Village Apparatus. There are also other elements in the form of the Village Consultative Body in the village government.

The Village Head, Village Apparatus, and BPD are the parties that get attention in this study. Internally, the Village government is related to the conflict between the Village Head and the Village Apparatus due to the decision of the Berora Village Head being elected to dismiss nine of his Village Apparatus. The next conflict is between the function of the Camat in approving or disapproving the dismissal of the nine Village Apparatus and the submission from the elected Berora Village Head. The conflict widened with the involvement of the PMD Service and the Sumbawa Regency DPRD through official answers that had legal force in governance arrangements.

Regarding the duties and authorities of the Village Head in PP Number 43 of 2014, there is no addition. The tasks carried out are the same as those stipulated in Law Number 6 of 2014, including the authority to dismiss Village Apparatus, which does not get a more specific description. 
It is important to disclose at the beginning the terms and tasks carried out by the Village Apparatus. It needs to be emphasized because it was used as one of the reasons the Village Head fired his village apparatus through the Berora Village Head Decree Number 140/429/VI/2020, which was sent to the Lopok District Government Head through a cover letter Number 045.2/430/VI/2020.

This regional regulation has been developed from PP No. 43 of 2014 because it only requires three provisions, namely 1) the lowest education is high school; 2) age level 20-42 years and 3) become a local village resident at least one year prior to registration. The requirements in the PP and Perda are general because the Village Apparatus has a unique and available task field, not involving competence. This context is essential because the Berora Village Head considered it in dismissing the nine Village Apparatus.

Regional regulations, including the Sumbawa Regency Regional Regulation Number 3 of 2015, further elaborates higher legislation (Government Regulations), particularly PP Number 43 of 2014 concerning Villages. In general, the content of the Regional Regulation contains the content in the context of implementing regional autonomy, co-administration tasks, and accommodating special regional conditions and or further elaboration of higher laws and regulations. In this regard, the existence of the Sumbawa Regency Regional Regulation Number 3 of 2015, especially related to the requirements for the appointment of Village Apparatuses, must not conflict with the conditions specified in PP Number 43 of 2014. It can declare this context to fulfill correctly because the content provides additional, so it's clearer.

According to the researcher, the contents of the requirements for the appointment of Village Apparatus should be more detailed, especially by distinguishing the requirements for each position (Village Secretary, Regional Executive, and Technical Executor). Details of these requirements can also be made through alternative Village Regulations so that they are following the conditions of each village. Still, there is no explanation for this in the Regional Regulation because these requirements are closed to point $\mathrm{k}$.

It was referring to the content above that the contents of the Village Apparatus requirements can be stated that there is nothing defective or contrary to the conditions for protection, humanity, nationality, kinship, archipelago, diversity in diversity, justice, equality of position, order and legal certainty, balance, and harmony. There is harmony with the regulations above and the possibility of meeting the needs of individuals, communities, and the state related to the requirements of the Village Apparatus. The problem is the detailed competence in each Village Apparatus position.

By law, the Village Head can dismiss the Village Apparatus if 1) dies, 2) own request, and 3) dismissed. Therefore, the case in this study was dismissed. The points in this article are the same as in Law Number 6 of 2014 with Regional Regulation Number 3 of 2015. Furthermore, explanations can be stopped regarding the dismissal of Village Apparatus, if the following occurs:

1. Age has reached 60 (sixty) years

2. Unable to carry out tasks on an ongoing basis or remain absent, either consecutively or not consecutively, for 6 (six) months

3. No longer meets the requirements as a Village apparatus;

4. Can no longer cooperate with the Village Head.

5. Violating the prohibition as a Village apparatus; or

6. Declared as a convict based on a court decision that has permanent legal force.

The six provisions above are more detailed than the provisions stipulated in Law Number 6 of 2014, only consisting of four points, namely 1) Even 60 years of age; 2) Permanent absence; 3) Does not meet the requirements as a Village Apparatus and 4) Violates the prohibition as a Village Apparatus. Points 3-5 are the basis for the elected Berora Village Head to dismiss the Village Apparatus. Of course, there will be different interpretations, resulting in polemics between the Elected Berora Village Head and the Village Apparatus, Camat, BPD Berora, PMD Service, and even the Chair of the Sumbawa Regency DPRD involved in it. It all boils down to the decision of the Administrative Court Number 65/2020/PTUN.MTR. 
The article regarding the dismissal mechanism above further elaborates paragraphs 3 and 4 of Article 53 of the Law. Number 6 of 2014, related to the dismissal of the Village Apparatus. Can state The points in the article in Perda Number 3 of 2015 to be clear so that they can become a work reference for all parties related to the Village Head's Decision to dismiss the Village Apparatus.

\section{Dismissal of Berora Village Apparatus according to Sumbawa Regency Regional Regulation Number 3 of 2015}

The Head of Berora Village in the Decree "Application for Recommendation for Dismissal of Berora Village Apparatus" Number 140/429/VI/2020 stated that the nine Village Apparatus no longer met the requirements Village Apparatus regarding Regional Regulation Number 3 of 2015. The reason for the urgency is that the Village Apparatus cannot improve performance and services to the people of Berora Village. The nine Village Apparatuses are:

1. Budi Hartadi: Head of Government

2. Syamsuddin: Head of welfare

3. Fatmah: General Affairs and Administration

4. Yulia Eka Raharni: Head of Planning

5. Muhammad Adam: Kadus Berora

6. M. Nur. MS: Kadus Sekayu A

7. Muhammad Saleh: Kadus Sekayu B

8. Ahmad HM. A: Serange Headquarters

9. Hamzah: Head of Pelam Pelam

Recommendation letter from the elected Berora Village Head (Sanapiah) dated June 23, 2020 (signed and stamped by Berora Village), indicating the validity of the recommendation letter addressed Sumbawa Regency to the Lapok sub-district head. The recommendation letter is accompanied by attachments that form the basis for the Village Head requesting a recommendation for dismissal, in the form of:

1. Statement letter from the Manager and Secretary of the BUMDes of Berora regarding the loan of Rp. 1,500,000 each, which was made by Budi Hartadi, Muhammad Adam, Syamsudin, M. Nur MS., and Ahmad yani. It includes loans made by the Berora Village Apparatus family.

2. The warning letter was given to Yulia Eka Raharini, related to leaving the office two times without permission and one time not entering without permission.

3. There was a village apparatus that dismissed a Hansip/Linmas named Burhanuddin.

4. Based on the Recommendation Letter above, the Lopok District Government was given a recommendation reply through Letter Number 904/77/VI/2020, the contents of which were to reject the proposal to dismiss the Berora Village Apparatus on behalf of:

1) Budi Hartadi: Head of Government

2) Syamsuddin: Head of welfare

3) Fatmah: General Affairs and Administration

4) Yulia Eka Raharni: Head of Planning

5) Muhammad Adam: Kadus Berora

6) M. Nur. MS: Kadus Sekayu A

7) Muhammad Saleh: Kadus Sekayu B

8) Ahmad HM. A: Serange Headquarters 
As for Hamzah (Kadus Pelam Pelam), related to 60 years, it is time to stop. The recommendation letter above was signed by the Lopok Head sub-district (Abubakar, S.Sos., M.Si) dated June 29, 2020, meaning there is a 6-day lag time, so this recommendation is declared valid from the aspect of time (seven days) or does not cause the application for advice from the Head of Berora Village to be invalid by itself, but must use the recommendations made by the Camat.

There is a void in the Legislation. In the form of the Sumbawa Regency Regulation Number 3 of 2015, in regulating the requirements of the Village Apparatus. Through the work of the Village Head and BPD, the Village Government cannot be relied on in translating and re-operationalizing a Regional Regulation because it is known that the quality of HR (Human Resources) in the Village is still relatively low. Normatively, regional regulations (including the Sumbawa Regency Regional Regulation Number 3 of 2015) must contain detailed requirements for village officials.

The Berora Village Head, in addition to using considerations of requirements as a Berora Village Apparatus, also uses references of violations in carrying out activities and authorities. The alleged violations were in the form of borrowing BUMDes funds, not entering and leaving without permission, and firing a Hansip.

The Berora Village Head could not use the reason for borrowing money from the BUMDes "Sakinah" as a reason for dismissal. This activity is legal. Moreover, it is categorized as a big mistake (the case is borrowed by the Berora Village Apparatus and carried out by the wife/husband). All residents who need criteria as consumers/customers have the same rights to use BUMDes business services. The involvement of all levels of society in using the products (goods and services) produced by the BUMDes "Sakinah" Berora is a supporter of the success of the business and economic development of the village community.

An unjustified action is to use his authority as the Berora Village Apparatus to corrupt the funds of the BUMDes "Sakinah" Berora. This fact does not happen, if there is insufficient credit, then the solution is a business solution, or a gradual deduction can be made from the allowance in question. The facts on the ground did not happen. The real action was to harm the BUMDes "Sakinah" Berora finances.

The reason that applies to one Berora Village Apparatus is the dismissal of Hansip so that in-depth analysis can be carried out. However, the fact is that the Berora Village apparatus does not have the authority to fire, so this case is unlikely to happen.

The requirements proposed above as the basis for the dismissal of the Berora Village Apparatus by the Village Head were rejected in response to the recommendation of the Lopok Camat, Sumbawa Regency. The request for a proposal to dismiss the Village Apparatus by the Berora Village Head was rejected by the Lopok Camat. The empirical fact occurred was that there were mutual arguments between the Berora Village Head and Lopok District. Even the Village Head's statement appeared that the Camat was not the village head's superior. Hence, his only role was to ratify the recommendation request.

Starting on July 23, 2020, in the form of a request for a recommendation for dismissal and giving each other answers, the involvement of the PMD Service and the Sumbawa Regency DPRD did not cause the Berora Village Head to cancel the clearance of the four Hamlet Heads. Judging from the requirements put forward, it turns out that the initial recommendation request that was justified by the abuse of authority from the Village Apparatus was not submitted for dismissal and led to only four sub-districts. The acknowledgment of the cancellation of the four Village Apparatuses, in the form of Technical Implementers, was not made by the Village Head of Berora, so it is very relevant to the reasoning of BPD Berora that the dismissal of the four Kadus was closely related to the village head election.

The above description is related to the statement of the Berora Village Head, who dismissed the decision that the Berora Hamlet Head no longer met the requirements as a Village Apparatus concerning 
the applicable legislation (Perda Number 3 of 2015). The Lopok Head Sub-district submitted various reasons to request a recommendation for dismissal, in which the Camat gave a refusal. At the same time sent a copy to the PMD Service and the DPRD. These two agencies also provided solutions through their respective tasks, in which these two agencies provided support for the decision of the Lopok Camat. Nevertheless, the Berora Village Head party persisted with his decision.

The considerations given by the Village Head are not only limited to the requirements of the Berora Village Apparatus, which can no longer be met, related to the new requirements. Thus, on the other hand, it is known in general and explained by the Subdistrict Lopok cannot apply the law retroactively. But, on the other hand, the initial official is appointed with conditions that refer to the previous statutory regulations. Therefore, a provision may not apply retroactively, even though this context is in criminal law, but also applies in various contexts.

The Village Head, in this case, has the idea that the Village Head is the head of government in the village area, which has full autonomy, without interference from the government above him. Therefore, the context of asking for recommendations was believed to be only an administrative procedure, so it must fulfill.

The reason for Berora Village Apparatus dismissal, both the requirements and the prohibition, cannot be fulfilled. The context of the requirements with advanced in the form of competence and inability to cooperate with the Village Head in carrying out service and empowerment tasks and other tasks cannot be justified. It was emphasized so because the elected Berora Village Head was inaugurated in the range of April 2020, while only two months of work could not be taken into consideration to provide an assessment of the workability of the Berora Village Apparatus.

The Berora Village Head, to carry out his authority to dismiss the Village Apparatus, can also be studied from the mechanism being implemented. Regional Regulation Number 3 of 2015, as a form of operationalization of PP Number 43 of 2014, has established a mechanism for dismissing Village Apparatus.

Dismissal of the Village Apparatus as a result of 1) not being able to carry out tasks on an ongoing basis or being unable to remain permanently either consecutive or not for 6 (six) months; 2) no longer fulfills the requirements as a Village apparatus; 3) can no longer cooperate with the Village Head and 4) violates the prohibition as a Village apparatus or violates points b, c, d and e of paragraph 3 article 13, then the dismissal mechanism is through written consultation with the sub-district head on behalf of the regent. The process of dismissal is evident in Article 14, with details of the process as follows:

1. The Village Head must conduct written consultations with the Camat on behalf of the Regent regarding the dismissal of the Village apparatus

2. The Camat, on behalf of the Regent, must provide a written recommendation containing the dismissal of the Village apparatus that has been consulted with the Village Head no later than 7 (seven) days after the written consultation is received

3. If the Camat does not provide a written recommendation for a maximum of 7 (seven) days as referred to in letter b, the Village Head may immediately dismiss the Village apparatus.

4. A written recommendation from the Camat on behalf of the Regent may accept or reject the dismissal of the Village apparatus; and

5. The sub-district head's written recommendation on behalf of the regent is used as the basis by the village head in dismissing village officials

The dismissal mechanism does not mention the possibility of resistance, either in the context of Administrative Efforts by the Village Head on the results of recommendations from the Camat in the dismissal of Village Apparatus or forms of resistance that are mutually retaliatory through letters, especially the Village Head can fight the results of recommendations that are refusal. 
It can state the existence of the Sumbawa Regency Regional Regulation Number 3 of 2015 in operationalizing Government Regulation Number 43 of 2014 and Law Number 6 of 2014 to be compatible, even though their operationalizing role is not contradictory. The researcher hopes that the content in Perda Number 3 of 2015 related to requirements is more operational, including the dismissal mechanism, which is final administratively based on the recommendation of the Camat, without any process of giving answers to each other between government officials.

In society can not demonstrate the arrogance of power at various levels of government. This condition was carried out by the Berora Village Head so that the Administrative Efforts carried out by the Berora Village Apparatus were barren (deadlocks/decisions had no legal meaning or force).

The decision of the Berora Village Apparatus (four Kadus Berora Village) to take legal action is classified as appropriate. So that an objection complaint was submitted through the Mataram Administrative Court on (register date; November 16, 2020, with case number 65/G/2020/PTUN.MTR) and processed for 146 days, then will issue the decision on April 13, 2021, with the decision to cancel the Decree of the Head of Berora Village Numbers 55, 56, 57 and 58; as well as Village Head Decrees Number 60, 61, 62 and 63 as well as restoring the good names of the four related Hamlet Heads.

\section{Legal Consequences of Dismissing Berora Village Apparatus that are not following Sumbawa Regency Regional Regulation Number 3 of 2015}

The polemic was resolved through two media, namely Administrative and Judicial Efforts through the Mataram Administrative Court. Administrative efforts were carried out by either the Berora Village Head or the Berora Village Apparatus, who was dismissed. This administrative effort resulted in a decision from the Subdistrict that the Village Head rejected the request for a recommendation to dismiss the Berora Village Apparatus. However, this refusal did not cause the Village Head to accept but to return to administrative efforts. The answer given by the Lopok Camat was to reject the dismissal of the Berora Village Apparatus because it was contrary to the Sumbawa Regency Regional Regulation Number 3 of 2015.

The error of the Berora Village Head in interpreting autonomy and authority of the Village Head in dismissing the Berora Village Apparatus caused the administrative effort to widen so that the Berora Village Apparatus received a defense from the Village Supervisory Board of Berora, the Community Empowerment Service of Sumbawa, and the Regional People's Representative Assembly of Sumbawa. As a result of the results of Administrative Efforts by the Berora Village Apparatus, on the one hand, the disobedience of the Berora Village Head resulted in the Village government not receiving Siltap funds, allowances, and other finances. On the other hand, village governments that do not run good governance may find it challenging to realize DAU.

The punishment in the form of a suspended financial policy indicates legal force from the Administrative Efforts won by the Berora Village Apparatus. Ideally, it can strengthen this administrative effort to force the Berora Village Head to cancel Decisions No. 55, 56, 57, and 58 and Decisions No. 60, 61,62 , and 63 .

In the context of legal remedies by the Berora Village Apparatus through the judiciary, obtain a decision from the Administrative Court Number 65/G/2020/PTUN MTR that the Decisions of the Berora Village Head Numbers 55, 56, 57, 58 as well as Decisions Numbers 60, 61, 62 and 63 were annulled. Furthermore, the Berora Village Head is also obliged to restore the good name or dignity of the dismissed Berora Village Apparatus.

On April 13, 2021, issued the Mataram Administrative Court's decision on this case was. It caused researchers to carry out follow-up research by conducting follow-up interviews with informants. As a result, information was obtained that the village head of Berora appealed. 
Berora Village apparatus as the dismissed party has taken administrative and legal efforts (PTUN media). Likewise, the Village Head who thinks that carrying out his authority has been given the right to provide answers during the administrative effort process. Similarly, by administrative Court. Therefore, it is confirmed that the disputing parties have provided their respective statements or information, according to the basis of the person concerned, exercising his authority and asking for his rights.

In the case of a dispute between the Village Head and his subordinates (Village Apparatus), there is no distinction between the two, not seen from the position held but purely from the substance of the dispute. Therefore, it has fulfilled justice for all parties, where there is openness in getting justice.

The authority, functions, and rights, including the position as a citizen, have been regulated so that no party is oppressed. The legal process through the Administrative Court and administrative efforts between the Village Head and the Village Apparatus has been carried out. The process and decisions have reflected the justice of all parties to the dispute in providing self-defense.

Justice does not mean that the wishes of all parties are fulfilled, but the concept is conformity to the applicable laws and regulations. Therefore, the next important thing is that the disputing parties must comply with existing laws and regulations, including decisions from Administrative Efforts and Administrative Court Justices.

\section{Conclusion}

Regional Regulation Number 3 of 2015, following the hierarchy of laws in force in Indonesia, appears as an implementing rule of the above legislation, namely PP Number 43 of 2014 concerning Implementation Rules of Law Number 6 of 2014 concerning Villages. Specifically regulates Village Apparatus, including controlling the dismissal and mechanism of release of Village Apparatus. The contents of this regional regulation are precise and in line with the above laws and regulations. The dismissal of the Berora Village Apparatus has violated the basis for the termination and its mechanism.

The dispute over the dismissal of the Village Apparatus by the Berora Village Head was resolved through two media, namely Administrative Efforts and the State Administrative Court (PTUN Mataram). The decision made through administrative efforts (Camat, strengthened by the Head of the Community and Village Empowerment Service and the Regional People's Representative Council through Commission 1) decided that the dismissal of the Berora Village Apparatus must be annulled. This decision was also strengthened by administrative sanctions in the freezing of Slitap and allowances for Village Apparatus (meaning for new Village Apparatuses appointed through Village Head Decree Number 66, 61, 62, and 63 of 2000). The same decision from the Mataram Administrative Court even asked the Berora Village Head to restore the dignity of the four village officials dismissed.

\section{Recommendation}

The content of Regional Regulation Number 3 of 2015 is straightforward, related to the dismissal of Village Apparatus and its mechanism. But a more critical aspect that needs to explain is the meaning of consultation from the Village Head with the Subdistrict regarding the dismissal of the Village Apparatus.

The hierarchical relationship between the Village Head and the Camat or other positions (Head of PMD Service and Commission 1 DPRD) must be clear, related explicitly to administrative efforts. This context is to provide clear and firm authority, including in imposing sanctions. It is recommended because financial sanctions can be imposed on the Village Government but cannot execute the substance of the case. Many cases like this occur in the Sumbawa district, so it is necessary to socialize the authority of the Village Head, and his upward and downward working relationships carried out by the PMD. This case takes up a 
lot of time and energy, thus interfering with village community services and other work that is the function of the Village Head and his apparatus.

\section{References}

Amiruddin, \& Asikin, Z., (2020), Introduction to Legal Research Methods, Jakarta: RajaGrafido Persada.

Assiddiqie, j., (1995), Position of Constitutional Law in Development, Journal of Constitutional Law UI, Vol.2 Number XXV.

Balai Pustaka Team, (1996)., Big Indonesian Dictionary, Jakarta, BP.

Berora BPD Report on the Polemic of the Appointment and Dismissal of Village Apparatus by the Berora Village Head, 2020.

Financial and Development Supervisory Agency (BPKP), (2015), Implementation Guidelines for Village Financial Management Guidance \& Consultation, Jakarta: BPKP.

Frans, M. S., (1992), Philosophy of Political Culture Points of Critical Thinking, Jakarta: Gramedia.

Handoyo, H. C., (2009), Indonesian Constitutional Law, Yogyakarta, Atma Jaya University.

Hanif, N., (2014), Village Administration: "Fake Government Units" in the State Administration System of the Republic of Indonesia (Case of Jabon Mekar Village, Parung, Bogor Regency), Jurnal Politica Vol.5. Number 1.

Haposan, S., (2016), Application of the Principles of the Rule of Law in Indonesia, Journal of Sociohumanities, Vol.18. Number 2.

Indonesia, the 1945 Constitution of the Republic of Indonesia, Jakarta.

Indonesia, Law Number 12 of 2011 concerning the Establishment of Legislation, Jakarta, 2011.

Indonesia, Law Number 6 of 2014 concerning Villages. Jakarta.

Indonesia, Law Number 30 of 2014 concerning Government Administration, 2014.

Indonesia, Government Regulation Number 43 of 2014 concerning Villages, Jakarta.

Indonesia, Sumbawa Regency Regional Regulation Number 3 of 2015 concerning Village Apparatus, Sumbawa, 2015.

Irwan, A., (2014), Initiating Indonesia as a legal state that makes its people happy, Journal of Yustisia, Issue 90.

Jefri, A., (2015), Interpreting State Law (Law Through State) in the Frame of the State of Law (Rechstaat), Hasanudin Law Review-Journal. Vol.1. Number 1.

Kusnardi, M., Ibrahim, H., \& Mujiburohman, D. A., (2017), Introduction to Constitutional Law, Yogyakarta, STPN Press.

Lopok Camat Report on the Implementation of Berora Village Government in Lopok District in 2020.

Lucky, W. S., (2003), Globalization \& Decentralization: Local Economic Perspective, Jakarta: Faculty of Economics UI. 
Marbun, S. F., (1997), State Administrative Courts and Administrative Efforts in Indonesia, Yogyakarta, Liberty, 1997.

Muhammad, M., (2017), Theory of Justice in Legal Protection for Village Heads in Implementing Village Policies (Case Study of Case Decision Number 66/Pid.Sus/Tpk/2015/PN. Sby), Journal of Mimbar Justitia, Vol.1. Number 1.

Muhamad, Y., et al. (2015). Annotation to Law Number 6 of 2014 concerning Villages, Jakarta: Pattiro.

Mujiburohman, D. A., (2017), Introduction to Constitutional Law, Yogyakarta, STPN Press.

Mukti, F., \& Yulianto, A., (2019), Normative \& Empirical Legal Research Dualism, Yogyakarta, Student Library.

Nyimas, L., (2016), Village Autonomy and the Effectiveness of Village Funds, LIPI-Journal of Political Research. Vol.13. Number 2.

Philipus, M. H., (2005), Introduction to Indonesian Administrative Law, Yogyakarta: Gajah Mada University Press.

Prans, A. T., \& Ubanus, O., (2019), Village Political Dynamics: A Study on Power Relations of Village Elites and Politics of Village Head Elections in Witihama District, East Flores Regency, Journal of Dinamika Warta Governance, Vol. 1. Number1.

Sarip, (2020), Political Law and Politicization of Village Law in the Indonesian Constitutional System, Journal of Bina Mulia Hukum, Vol.4. Number2.

Setyo, N., (2013), Democracy, and Governance in the Concept of Villages and Villages, Journal of Cita Hukum, Vol.1. Number 2.

Sony, Maulana, et al., (2018). Introduction to Legislation Science, Open University, Jakarta, 2018.

Syafi'i, (2008), New Paradigm of Regional Economic Development Policy, Malang: Averroes Press.

Surajiwo, (2018) Justice in the Pancasila Legal System, Journal of Ikraith Humanira, Vol.2. Number 3.

\section{Copyrights}

Copyright for this article is retained by the author(s), with first publication rights granted to the journal.

This is an open-access article distributed under the terms and conditions of the Creative Commons Attribution license (http://creativecommons.org/licenses/by/4.0/). 